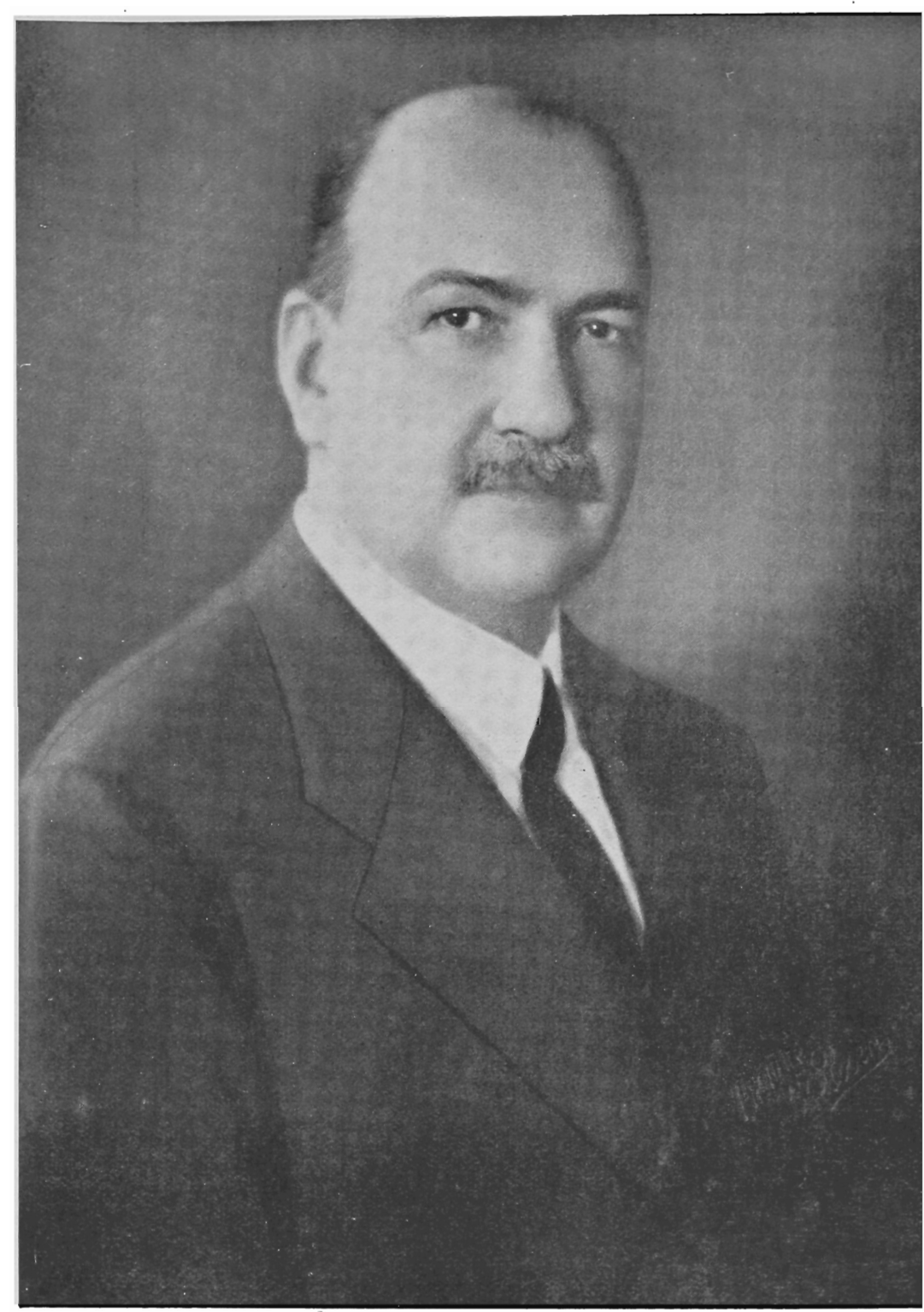

PRO'FESSOR DOUTOR THEOPHILO

BENEDITO DE SOUSA CARVALHO 


\section{Professor Theopihlo Benedicto de Sousa Carvalho}

Por ocasião da reabertura dos Cursos Juridicos da Universidade de São Paulo, a 31 de março do corrente ano, foi prestada pela congreģação da Faculdade de Direito homenagem ao professor Theophilo Benedicto de Sousa Carvalho que, aposentando-se, acabava de deixar a cadeira de direito internacional, depois de ter sido catedrático cerca de vinte e quatro anos.

O professor Vicente Ráo, lente de direito civil, antes de proferir a lição inaugural, referiu-se em justos conceitos, ao professor Sousa Carvalho que, despedindo-se dos colegas naquele momento, recebia a mais sincera prova de estima e admiração dos professores e dos seus antigos alunos.

Profundamente comovido, o homenageado pronunciou bela oração de despedida e agradecimento que vai reproduzida a seguir.

“Senhores - Eu não vou prelecionar, não vou dar aula e nem fazer um discurso; e isto por duas razões decisivas e imperiosas. A primeira é que a Lei me não consente, e a segunda é que o meu coração jamais foi asilo de crueldade, e cruel eu seria se viesse com um discurso interromper o gôso que estamos todos sentindo, graças á brilhante aula inaugural que acaba de ser dada.

Não seria até razoavel fizesse eu que o inverno da minha velhice se intrometesse como perturbador da continuidade de um instante prazenteiro causado pela primavera moça e brilhante de um Vicente Ráo.

Minhas palavras têm que se cingir ao cumprimento estrito de um dever amistoso, qual o do agradecimento que 
faço ao meu eminente colega, prof. Ráo, pelas generosas referências que acaba de fazer á minha humilde individualidade, e a todos quantos, nesta sessão pública e solene da Congregação, tomam parte nas gentis homenagens feitas á minha pessoa.

$\AA$ mocidade acadêmica estendo tambem meus agradecimentos muito cordiais, pelo bem que me proporcionou ajudando-me no cumprimento dos meus deveres e me afastando de coisas tristes da vida, como que me preparando para não ouvir os uivos dos mochos solitários que do alto dos campanários soltam sangrentas canções nos bailes da meia noite, de que fala o poeta e, me fazia "viver, beber perfume na flor silvestre que embalsama os ares.

Grato ainda a essa mesma mocidade acadêmica, porque foi ela quem me ensinou como suavizaria minha vida intelectual no mais estreito aconchego com literatos e poetas, graças aos quais bem não ia sentindo o acelerar das descidas dos degraus da escada que me iam, cada vez mais, afastando da vida moça.

Ensinei ciência, na diminuta medida das minhas fôrças, aos meus alunos, no propósito de oferecer-lhes um jardim; e eles, em compensação, me ensinaram tambem como embelezá-lo, of ertando as flores.

Assim irmanados, caminhamos unidos, para um ideal de beleza, já sintetizado por alguem, que havia dito:

"A ciência é um jardim, a literatura é a flor; sem a flor, que beleza terá o jardim?"

E, na situação em que agora estou colocado, com o afastamento "compulsório" dessa estreita e boa companhia, nada mais me resta senão agarrar-me mais intimamente com os poetas e literatos, que tanto bem veem fazendo ao meu espírito, já tendo iniciado a execução deste plano com a deliciosa leitura feita dos "IF" do poeta inglês nos "SI. ", de Guilherme de Almeida, o príncipe dos literatos modernos brasileiros. 
Em conclusão

Depois de variadas refregas, não cruentas, mas nobres e edificantes, om que tomaram parte afamados juristas, salvo eu, concorrendo para o ingresso no alto culto da Jurisprudência nesta Casa de Ensino Superior, me foi dado o ingresso almejado; prometi bem cumprir os deveres do meu magistério.

Se bem executei esse compromisso, di-lo-ão melhor e mais propriamente do que eu, as brilhantes turmas (e não foram poucas) que por mim passaram aqui deixando-me em estacada á contemplação das suas gloriosas vitórias na vida prática intelectual e moral.

E neste instante, em que desaparece a plenitude do meu magistério, só me restará aguardar a hora fatal em que a "lágrima" significativa ha de surgir para, derramada, se evolar nas azas brancas de uma saudade viva, e então, buscar olhar, por derradeiro momento, este ninho do pensamento e do estudo, este castelo de honestidade intelectual, esta menina dos meus olhos; e, de pé, se possivel, bradar, parodiando os soldados de Cesar:

"Ave! Faculdade de Direito! Moriturus, Te Saluto!" 